\title{
Integrated electrochemical processes for textile industry wastewater treatment: system performances and sludge settling characteristics
}

\author{
Hanane Afanga ${ }^{1}$, Hicham Zazou ${ }^{1}$, Fatima Ezzahra Titchou' ${ }^{1}$, Youness Rakhila², Rachid Ait Akbour ${ }^{1}$, \\ Abdellah Elmchaouri ${ }^{2}$, Jaafar Ghanbaja ${ }^{3}$ and Mohamed Hamdani ${ }^{1^{*}}$
}

\begin{abstract}
Textile wastewater containing toxic dyes needs efficient treatment before being released into the environment. Certain dyes are known or presumed to have carcinogenic potential for humans. In this work, hybrid electrochemical processes including electrocoagulation (EC) alone and combined with electro Fenton (EF), anodic oxidation (AO) and peroxicoagulation $(\mathrm{PC})$ were tested to treat real textile wastewater using a batch reactor. A sequential EC and EF (EC-EF) process was found to be more effective. The experimental results indicated that the effectiveness of the treatment decreases in the following order: EC-EF $>E C-A O>E C-P C>E C$. EC-EF results showed a decrease in chemical oxygen demand (COD, 97\%), total organic carbon (98\%), total suspended solids (98\%), and the concentration of metal species; showing that the treatment of such wastewater type can be achieved by combined EC-EF process in a one-pot bench-scale reactor. The electrical energy consumption, the iron dissolution, and the biological oxygen demand/COD ratios of EC and EC-EF processes were evaluated. Characterization of the sludge generated during EC treatment at current density of $20 \mathrm{~mA} \mathrm{~cm}^{-}$ ${ }^{2}$ was carried out. Precipitation, adsorption, and electrochemical oxidation/reduction of organic dyes and metallic ions occurred during the treatment. This investigation shows the efficiency of combined EC-EF to treat textile wastewater.
\end{abstract}

Keywords: Textile wastewater, Electrocoagulation, Electro-Fenton, COD, TOC, BOD

\section{Introduction}

The textile industry requires very large quantities of water during manufacturing and processing procedures, being major consumer of water [1]. This industry uses about 10,000 different dyes, and more than $0.7 \mathrm{Mt}$ of these dyes are annually produced worldwide [2]. Ten to fifteen percent of these dyes are released to the environment which constitutes one of the biggest environmental problems of the twenty-first century. These products cause serious damage to the environment due to the high concentration of color and dissolved matter in wastewater $[3,4]$. The textile wastewater contains a wide range of pollutants including organic persistent and toxic substances, heavy metals either in the free form or adsorbed onto the suspended solids, and inorganic

\footnotetext{
* Correspondence: hamdani.mohamed@gmail.com

${ }^{1}$ Chemical Department, Ibn Zohr University, 80060 Agadir, Morocco

Full list of author information is available at the end of the article
}

compounds [5]. Azo dyes, characterized by the presence of at least one azo group $(-\mathrm{N}=\mathrm{N}-)$, are one of the largest groups of synthetic dyes used in industrial applications [6]. These azo dyes are metabolized to colorless, possibly carcinogenic amines in living beings [7]. Therefore, the primordial tasks were focused to treat these wastewatercontaining dyes. The treatment method developed and proposed in this paper aims to eliminate dye contamination in the most efficient manner, both from a technical and economic point of view (cost-effectiveness must be taken into account).

Electrocoagulation (EC) is one of the most applied electrochemical methods in wastewater treatment [8]. EC is based on the electrochemical dissolution of sacrificial metal electrodes (Iron/Aluminum) into soluble or insoluble species according to the $\mathrm{pH}$ of the solution, as described in a seminal review article [9]. The coagulant (dissolved metal hydroxides) is generated continuously 
by applying an electric current that forms the flocs [10]. Therefore, these flocs create a blanket of sludge that entraps and bridges colloidal particles still remaining in the solution to float or to settle.

Electro-Fenton (EF) is one of the electrochemical advanced oxidation processes (EAOPs) that has attracted great attention for wastewater treatment. It is an environmentally friendly technology capable of electrochemically producing hydroxyl radical $\left(\mathrm{E}\left({ }^{\circ} \mathrm{OH} / \mathrm{H}_{2} \mathrm{O}\right)=2.80 \mathrm{~V}\right.$ vs. SHE), a very powerful oxidant. Hydroxyl radicals are able to oxidize a wide range of organic compounds [11]. Thanks to its ability to produce in situ $\mathrm{H}_{2} \mathrm{O}_{2}$ by cathodic reduction of oxygen and under the presence of $\mathrm{Fe}^{2+}$ as a catalyst, $\mathrm{H}_{2} \mathrm{O}_{2}$ is decomposed to form ${ }^{\circ} \mathrm{OH}$ radicals from Fenton's reaction [12, 13]. For this process, it is well known that the maximum of ${ }^{\circ} \mathrm{OH}$ production is reached at $\mathrm{pH}$ around $3[11,14]$. To avoid the addition of the catalyst $\left(\mathrm{Fe}^{2+}\right.$ ions) into the solution and to decrease the operational cost, it would be better to generate $\mathrm{Fe}^{2+}$ in situ via the EC process [14]. In this context, it could be interesting to combine the two processes (electrocoagulation and electro-Fenton) in the same electrochemical reactor in order to decrease costs and increase the degradation of chemical oxygen demand (COD), total organic carbon (TOC), and the removal total suspended solids (TSS). In recent years, EAOPs coupled with EC have been developed for the prevention and remediation of environmental pollution, especially for industrial discharges. Table 1 lists the recent studies using integrated treatment of industrial effluents, showing that the elimination of the pollutants can be achieved when the adequate process is employed.

The main objective of this study is to treat industrial textile wastewater to minimize their pollution load and to enhance their biodegradability using integrated electrochemical processes.

\section{Materials and methods}

\section{Characteristics of textile wastewater}

The textile industry wastewaters were collected from Mohammedia city in Morocco and contained a mixture of azo dyes with methylene blue as the main dye, and inorganic compounds (nitrogen, phosphorus, potassium, etc.). The wastewater was filtered using a pre-filtration grid to remove large suspended solids before being used for the subsequent study.

\section{Experimental apparatus and operating conditions}

The experimental set-up for the EC consisted of a reactor $(500 \mathrm{~mL}$ beaker) containing two iron plate electrodes $(11 \times 7.5 \times 0.2 \mathrm{~cm})\left(82.5 \mathrm{~cm}^{2}\right)$ with a purity of $99.5 \%$, with an inter-electrode distance of $1.5 \mathrm{~cm}$ and connected to a power supply. The EF reactor consisted of a boron-doped diamond (BDD) anode, film deposited on a niobium substrate $(10.0 \times 4.0 \times 0.2 \mathrm{~cm})$, from Condias (Germany) and a tridimensional carbon felt (CF) cathode $(14.0 \times 5.0 \times 0.6 \mathrm{~cm})$, supplied by $\mathrm{Hi}-\mathrm{Tech}$ Carbon Co. (China). The chemicals $\left(\mathrm{H}_{2} \mathrm{SO}_{4}, \mathrm{NaOH}\right)$ were purchased from Sigma-Aldrich, D-glucose and Dglutamic acid standards and Allylthiourea as nitrification inhibitor were obtained from Sigma to perform BOD measurements. All solutions, except for the real industrial effluent, were prepared using deionized water. Sketches of the setup and involved reactions are depicted in Fig. 1.

In each experiment, approximately $400 \mathrm{~mL}$ of real textile wastewater were placed in the electrolytic reactor. The $\mathrm{pH}$ of the solution was adjusted to the desired level using a dilute solution of sulfuric acid and sodium hydroxide (initial wastewater $\mathrm{pH}$ was 8.75 for $\mathrm{EC}$ and adjusted to $\mathrm{pH} 3.00$ for $\mathrm{EF}$ ) prior to the experiment and agitated with a magnetic stirrer at $200 \mathrm{rpm}$. In the case of EF, prior to electrolysis, compressed air was bubbled for $10 \mathrm{~min}$ in order to saturate the aqueous solution with $\mathrm{O}_{2}$. The electrochemical cell was operated with imposed current densities for both EC and EC-EF (20 and $10 \mathrm{~mA}$ $\mathrm{cm}^{-2}$, respectively) during $60 \mathrm{~min}$ of each treatment. These operating conditions (current densities and $\mathrm{pH}$ values and electrolysis time) were previously optimized and the operating conditions for other techniques are described, in our previous work [21].

Table 1 Recent studies on integrated treatment of industrial wastewater

\begin{tabular}{|c|c|c|c|c|}
\hline Treatment process & Cell configuration (Anode/Cathode) & Wastewater type & $\begin{array}{l}\text { Maximum mineralization } \\
\text { efficiency, \% }\end{array}$ & Reference \\
\hline$E C^{a}-E F^{b}$ & $\mathrm{Cu} / \mathrm{Cu} /-\mathrm{BDD}^{\mathrm{C}} / \mathrm{Cu}$ & Oil and grease industry & 99 & [15] \\
\hline EC & $\mathrm{Fe} / \mathrm{Fe}, \mathrm{Al} / \mathrm{Al}$ & Paint manufacturing & 93,94 & [16] \\
\hline EC & $\mathrm{Fe} / \mathrm{Fe}, \mathrm{Al} / \mathrm{Al}$ & Textile & 76,65 & {$[17]$} \\
\hline$E C-P C^{d}$ & $\mathrm{Fe} / \mathrm{Fe}-\mathrm{Fe} / \mathrm{Fe}$ & Various chemical and textile industries & 77 & [18] \\
\hline $\mathrm{EC}-\mathrm{O}_{3}$ & $\mathrm{Fe} / \mathrm{Fe}$ & Tannery plastics and textile industries & 60 & [19] \\
\hline $\mathrm{EC}-\mathrm{H}_{2} \mathrm{O}_{2}$ & $\mathrm{Al} / \mathrm{Al}$ & Plastics industry & 90 & {$[20]$} \\
\hline$E C-A O^{e}$ & $\mathrm{Fe} / \mathrm{Fe}-\mathrm{BDD}^{\mathrm{C}} / \mathrm{Fe}$ & Textile industry & 99 & [21] \\
\hline
\end{tabular}

Eelectrocoagulation; ${ }^{\mathrm{b} E l e c t r o-F e n t o n ;}{ }^{\mathrm{C} B o r o n-d o p e d ~ d i a m o n d ;}{ }^{\mathrm{d}}$ Peroxi-coagulation; ${ }^{\mathrm{e}}$ Anodic oxidation 


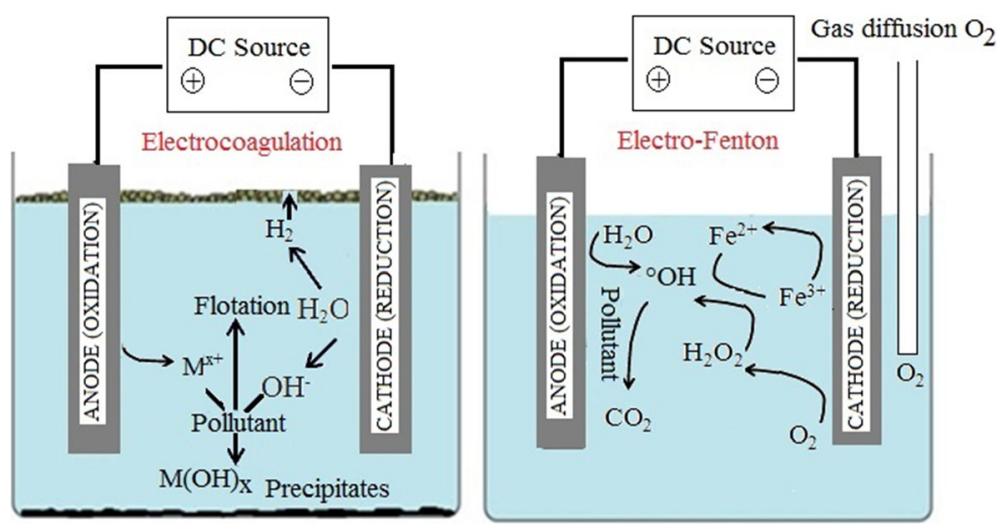

Fig. 1 Electrocoagulation and electro-Fenton experimental set-up containing power source and electrodes. In case of EC test, Fe-Fe electrodes are used while BDD anode, CF cathode, and $\mathrm{O}_{2}$ saturated effluent are used in the case of EF test

In the case of EC, the collected samples were centrifuged at $6000 \mathrm{rpm}$ for $10 \mathrm{~min}$ to settle the flocculated material. After each run, the iron electrodes were washed with $\mathrm{HCl}(10 \%)$, deionized water, and dried at room temperature. In addition, the sludge generated by the $\mathrm{EC}$ process was dried in the oven at $105 \pm 3{ }^{\circ} \mathrm{C}$ for $4 \mathrm{~h}$.

\section{Analytical procedures}

The UV-Visible spectrophotometer (Model Jasco V-630) was used to determine the dye concentration in textile effluent at maximum absorbance band that immerged at $650 \mathrm{~nm}$ (Fig. 2). The $\mathrm{pH}$ values were measured with Hanna instrument. The COD values were determined by a standardized method using spectrophotometer (Model HACH DR 6000). TOC measurements were determined by injection of $50 \mu \mathrm{L}$ of samples through thermal catalytic oxidation at $680^{\circ} \mathrm{C}$ using TOC-L SHIMADZU analyzer.

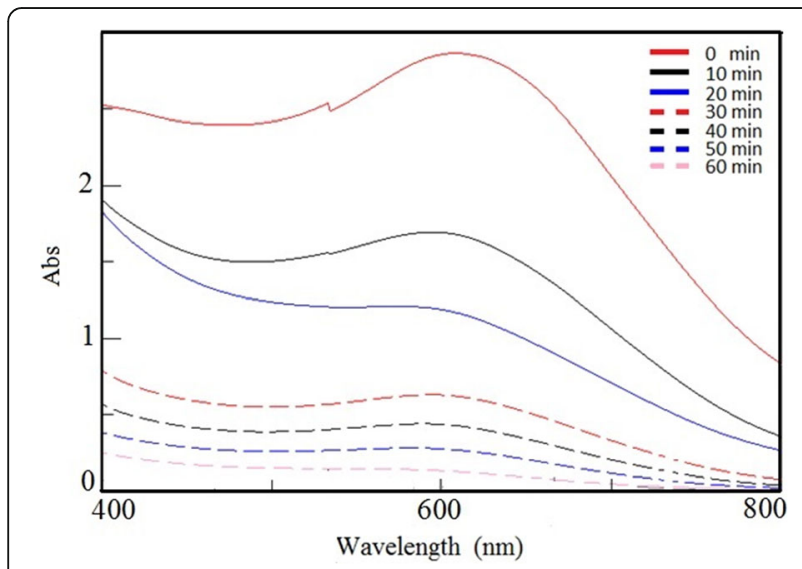

Fig. 2 UV-Vis spectra changes in textile wastewater treated with electrocoagulation at $20 \mathrm{~mA} \mathrm{~cm}^{-2}$
BOD values were determined in accordance with the standard methods using Lovibond incubator [22].

Total nitrogen (TN) content was measured by Dumas method Thermo Scientific (Flash 2000) [23]. $\mathrm{NH}_{4}{ }^{+}$values were obtained according to the standard method for water and wastewater using colorimetric method [24]. An unfiltered sample was taken for the determination of TSS following the standard method; the sample is filtered through a pre-weighed filter. The metal concentration in wastewater samples and the obtained dried sludge were carried out by Optical Emission Spectroscopy (ICP-AES, iCAP 6300 model SERIES THERMO). The floated (foam) and the decanted sludge were recovered separately at the end of the treatment and dried in an oven at $105 \pm 3^{\circ} \mathrm{C}$ [25] for $4 \mathrm{~h}$ in order to remove water from the samples before weighing to estimate the amount of dried sludge formed by EC. Then, the dehydrated sludge was calcined in the ambient atmosphere in the oven at $300^{\circ} \mathrm{C}$ for $1 \mathrm{~h}$. The sludge morphology and its metallic composition were characterized using high resolution scanning electron microscopy (SEM) (FEG Zeiss Gemini 500, Germany) provided with energy-dispersive Xray spectroscopy (EDS) (DDS Oxford model). EDS allows a simultaneous determination of metallic elements of the sludge. Additionally, transmission electron microscopy (TEM) investigations were carried out using a JEM-ARM 200F Cold FEG TEM/STEM operating at $200 \mathrm{kV}$ and equipped with a spherical aberration probe and image correctors (point resolution $0.12 \mathrm{~nm}$ in TEM mode and 0.078 $\mathrm{nm}$ in STEM mode) for structure and morphology. Moreover, X-ray diffraction (XRD) analysis was performed to the samples using (Bruker D8 Advance) with $\mathrm{Cu} \mathrm{K}_{\alpha 1}$ radiation (wavelength $\mathrm{WL}=1.5406 \AA$ ).

\section{Results and discussion}

\section{Physicochemical analysis of wastewater}

Physicochemical parameters of textile wastewater are shown in Table 2. The colored effluent is almost neutral 
Table 2 Main characteristics of textile wastewater

\begin{tabular}{ll}
\hline Parameters & Textile effluent \\
\hline $\mathrm{COD}\left(\mathrm{mg} \mathrm{L}^{-1}\right)$ & 325 \\
TOC $\left(\mathrm{mg} \mathrm{L}^{-1}\right)$ & 52 \\
BOD $\left(\mathrm{mg} \mathrm{L}^{-1}\right)$ & 35 \\
TSS $\left(\mathrm{mg} \mathrm{L}^{-1}\right)$ & 49 \\
Temperature $\left({ }^{\circ} \mathrm{C}\right)$ & 22 \\
Color & Blue black \\
pH & 8.75 \\
Conductivity $\left(\mathrm{mS} \mathrm{cm}^{-1}\right)$ & 2.5 \\
TN $\left(\mathrm{mg} \mathrm{L}^{-1}\right)$ & 40 \\
$\mathrm{P}\left(\mathrm{mg} \mathrm{L}^{-1}\right)$ & 0.2 \\
$\mathrm{Cl}{ }^{-}\left(\mathrm{mg} \mathrm{L}^{-1}\right)$ & 1.2 \\
\hline
\end{tabular}

with low pollution charges. The high electrical conductivity of the wastewater denotes the presence of dissolved salts in the effluent.

\section{Integrated EC-EF}

The anodic dissolution of the iron electrode inside the electrolytic cell in the case of EC promotes the generation of ferrous ions $\left(\mathrm{Fe}^{2+} / \mathrm{Fe}^{3+}\right)$ which react with hydroxides ion $\left(\mathrm{OH}^{-}\right)$in solution to produce $\mathrm{Fe}(\mathrm{OH})_{2(\mathrm{~s})}$, and $\mathrm{Fe}(\mathrm{OH})_{3(\mathrm{~s})}$. These iron hydroxides act as coagulant/ flocculent for the suspended solids to form flocs. These flocs have large surface area which is beneficial for a rapid adsorption of organic dye compounds present in textile wastewater and trapping of colloidal particles which sediment or float afterward.

Figure 2 shows the absorption spectra of the textile wastewater between $400 \mathrm{~nm}$ and $800 \mathrm{~nm}$ versus time of EC treatment. The obtained absorbance decreased continuously to diminish and disappear almost completely after $60 \mathrm{~min}$ of electrolysis.

The dissolved iron (sacrificial electrode), $\mathrm{m}_{\mathrm{Fe}}$, was calculated after considering the experimental conditions which were current intensity $\mathrm{I}=1.6 \mathrm{~A}$ and time $\mathrm{t}=60 \mathrm{~min}(3600 \mathrm{~s})$ of electrolysis using the Faraday's law (Eq. 1) [26]:

$$
\mathrm{mFe}=\frac{\mathrm{I} \times \mathrm{t} \times \mathrm{M}_{\mathrm{Fe}}}{\mathrm{n} \times \mathrm{F}}
$$

where $\mathrm{M}_{\mathrm{Fe}}$ is the molecular weight of $\mathrm{Fe}\left(55.9 \mathrm{~g} \mathrm{~mol}^{-1}\right)$, $\mathrm{n}(n=2)$ is the number of electrons transferred in the reaction at the electrode, and $\mathrm{F}$ the Faraday constant $\left(\mathrm{F}=96,500 \mathrm{C} \mathrm{mol}^{-1}\right)$. The maximum amount of ferrous ions $\left(\mathrm{Fe}^{2+}\right)$ electrolyzed in these experimental conditions was $0.48 \mathrm{~g}$.

The electrical energy consumption (EEC) per unity mass of removed TOC may be expressed in $\mathrm{kWh} \mathrm{kg}^{-}$
${ }^{1}$ an economical parameter calculated based on Eq. (2) [21].

$$
\mathrm{EEC}=\frac{\mathrm{U} \times \mathrm{I} \times \mathrm{t}}{\mathrm{V} \times\left(\mathrm{R} \times \mathrm{TOC}_{0}\right)}
$$

where $\mathrm{U}, \mathrm{I}, \mathrm{t}$, and $\mathrm{V}$ are cell voltage $(\mathrm{V})$, electrical current intensity (A), electrolysis time (h), and volume of wastewater (L) respectively. $\mathrm{R}$ is TOC removal efficiency and $\mathrm{TOC}_{0}$ is initial TOC concentration $\left(\mathrm{g} \mathrm{L}^{-1}\right)$.

The pollutant removal efficiencies (RE, \%) are calculated using Eq. (3) [27].

$$
\operatorname{RE}(\%)=\frac{\left(C_{0}-\mathrm{C}\right) \times 100}{C_{0}}
$$

In which, $\mathrm{C}$ is the TOC, COD or TSS value of treated aqueous solution $\left(\mathrm{mg} \mathrm{L}^{-1}\right)$ and $\mathrm{C}_{0}$ is the initial relating concentrations $\left(\mathrm{mg} \mathrm{L}^{-1}\right)$.

According to our previous study [21], treatment of textile wastewater by EC coupled with various EAOPs such as electrocoagulation-anodic oxidation (EC-AO), electrocoagulation-peroxicoagulation (EC-PC), EC-EF processes showed the effectiveness of sequential treatment of these processes than the individual process. Figure 3 shows the TOC removal and energy consumption obtained using EC and EC-EF for textile wastewater treatment. It also shows the results previously obtained in the same way by other combined processes such as $\mathrm{EC}-\mathrm{AO}$, and EC-PC for comparison. The experiments show that the EC technique alone has low effectiveness (44\% of TOC removal) and highest energy consumption (3 $\mathrm{kWh} \mathrm{kg}^{-1}$ of removed TOC using current density of $20 \mathrm{~mA} \mathrm{~cm}^{-2}$ ). Better efficiency is obtained with EC-EF process with high TOC removal and low energy consumption $\left(0.45 \mathrm{kWh} \mathrm{kg}^{-1}\right.$ of removed TOC using current density of $10 \mathrm{~mA} \mathrm{~cm}^{-2}$ ). Therefore, an analysis of operating costs was computed and compared with EC-PC and EC-AO process. The energy consumption

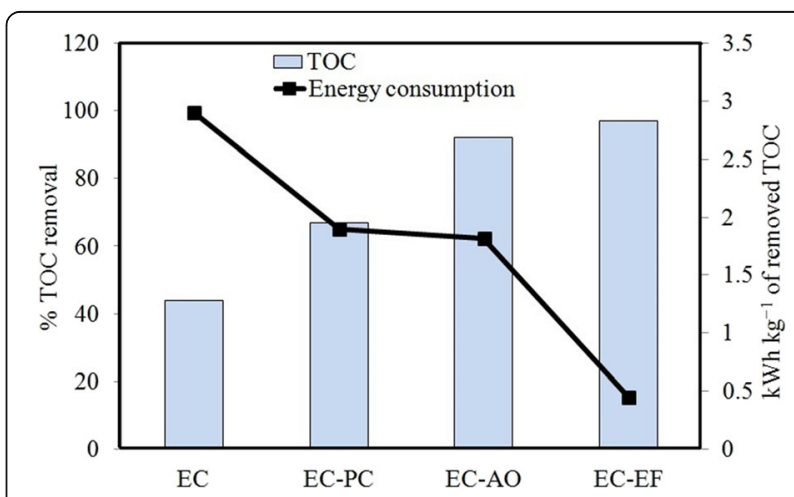

Fig. 3 TOC removal and energy consumption of various processes for textile wastewater treatment: $\mathrm{EC}$ with $\mathrm{pH}=8.75$ at I $=20 \mathrm{~mA}$ $\mathrm{cm}^{-2}$ followed by EF, PC and $\mathrm{AO}$ with $\mathrm{pH}=3$ and $\mathrm{I}=10 \mathrm{~mA} \mathrm{~cm}^{-2}$ 
for $1 \mathrm{~kg}$ of removed TOC is in decreasing order: EC (3 $\left.\mathrm{kWh} ; 20 \mathrm{~mA} \mathrm{~cm}^{-2}\right)>$ EC-PC $\left(1.9 \mathrm{kWh} ; 10 \mathrm{~mA} \mathrm{~cm}^{-2}\right)>$ EC-AO $\left(1.82 \mathrm{kWh} ; 10 \mathrm{~mA} \mathrm{~cm}^{-2}\right)>$ EC-EF $(0.45 \mathrm{kWh}$; $10 \mathrm{~mA} \mathrm{~cm}^{-2}$ ). Bener et al. [28], had used EC process for treating the real textile wastewater. From their findings, an operating cost including electrode consumption can be deduced which is equal to $2.75 \mathrm{kWh} \mathrm{kg}^{-1}$ of removed TOC using a current density of $25 \mathrm{~mA} \mathrm{~cm}^{-2}$.

The combined treatments were found to be more reliable and economical for treating textile industry wastewater than single processes [29]. In the case of EC-EF, the mineralization of organic matter reached $97 \%$. The effectiveness of EC-EF is due to the capacity of the electrolytic cell (in EF step) to produce $\mathrm{H}_{2} \mathrm{O}_{2}$ and to regenerate $\mathrm{Fe}^{2+}$ on the CF (electro-generation of Fenton reagent) which leads to the production of hydroxyl radicals in solution. These hydroxyl radicals generated on the anode surface (BDD anode) which has a high oxygen evolution overpotential attacked the organic pollutants to produce $\mathrm{CO}_{2}$, inorganic ions, and water [30].

Figure 4 shows the biodegradability of textile wastewater characterized by $\mathrm{BOD} / \mathrm{COD}$ ratio [26]. The final COD value is highly decreased from 325 to $12 \mathrm{mg} \mathrm{L}^{-1}$, while BOD value decreased slightly from 35 to $12 \mathrm{mg} \mathrm{L}^{-}$ ${ }^{1}$ of $\mathrm{O}_{2}$. Therefore, it is evident that EC-EF combination is an effective process for dye removal from textile wastewater. In addition, it appears that the EC-EF treatment enhances the biodegradability of the effluent by transforming non-biodegradable compounds into more biodegradable matter. Moreover, the ratio BOD/COD increases considerably to reach 0.46 after EC-EF treatment in contrast of 0.1 and 0.14 for initial effluent and after EC treatment, respectively. The initial biodegradability of this wastewater is very low even after EC treatment alone. This result is in accordance with many research papers that used advanced oxidation processes

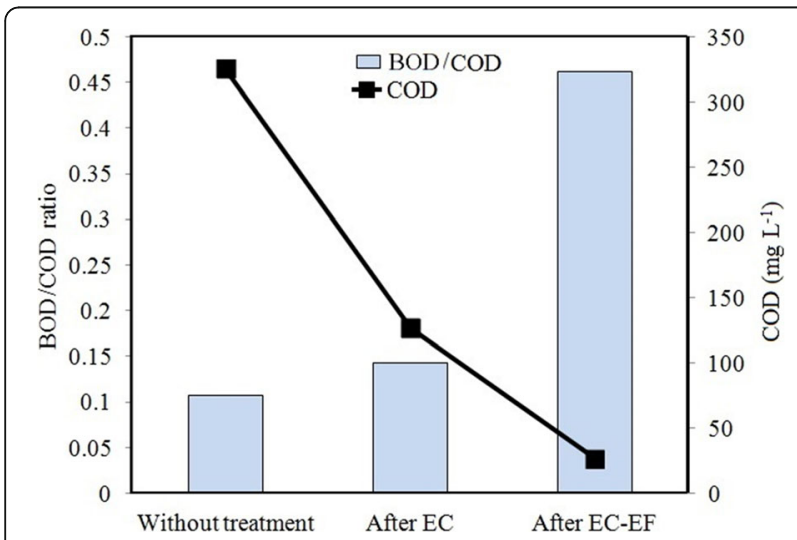

Fig. $4 \mathrm{COD}$ and $\mathrm{BOD} / \mathrm{COD}$ ratio for the textile wastewater before and during treatment: $\mathrm{EC}$ with $\mathrm{pH}=8.75$ at I $=20 \mathrm{~mA} \mathrm{~cm}^{-2}$ followed by $\mathrm{EF}, \mathrm{PC}$ and $\mathrm{AO}$ with $\mathrm{pH}=3$ and $\mathrm{I}=10 \mathrm{~mA} \mathrm{~cm}^{-2}$ such as Fenton, which improves the biodegradability of recalcitrant pollutants in wastewater [26].

\section{Characteristics of treated effluent and metal-ions removal}

The main characteristics of textile wastewater before and after treatment are summarized in Table 3. TSS was measured before and after treatment. EC can reduce TSS concentration via destabilization of colloidal pigment particles with positive surface charge by the negatively charged oxy/hydroxy-metal ions produced during the process [31]. It was found that TSS removal exceeded 90 and $98 \%$ by EC and EC-EF respectively after $60 \mathrm{~min}$ of electrolysis for each treatment step. The TN removal efficiency was 25 and 32\% for EC and EC-EF, respectively. The phosphorus removal increases with the electrolysis time, the maximum removal was determined up to $50 \%$ with EC-EF while the concentration of sulfate increased to $120 \mathrm{mg} \mathrm{L}^{-1}$. The increase of $\mathrm{SO}_{4}{ }^{2-}$ concentration can be explained by the destruction of the organic pollutants and consequently the release of the ions in the solution [32]. Generally, except sulfate, all other ions (metallic ions) continue to decrease through EC treatment and with EC-EF, while no significant difference was observed on the conductivity of the solution between the initial effluent and after EC-EF treatment.

The removal efficiencies of all metals by EC from wastewater were between 54 and $89 \%$ and between 60 and $97 \%$ after EC-EF treatment (Table 3). The removal amount of heavy metals by EC from the wastewater may be found in the sludge. In these operating conditions, the removal efficiencies of $\mathrm{Cu}, \mathrm{Mn}, \mathrm{Zn}, \mathrm{Fe}$ and $\mathrm{Cr}$ are $74,89,75,84$, and $74 \%$ after EC treatment alone and 82, 93, 94, 97, and $81 \%$ after EC-EF treatments, respectively.

\section{Characterization of the sludge Chemical element composition}

The sludge characterization is important in order to gain information on the formed sludge for proposing its adequate treatment, disposal, or reuse (optimization of conditioning, dewatering, incineration treatment and landfilling operations). Sludge dewatering is one of the main unit processes in sludge treatment as it minimizes sludge volumes for final disposal [33]. A measurement protocol for sludge produced (precipitate and flotation sludge) has been proposed for $400 \mathrm{~mL}$ of textile wastewater. The sludge is separated into two types, decanted and floated parts with the weight of about 1 and $1.1 \mathrm{~kg}$ of hydrated sludge per $\mathrm{kg}$ COD removed, respectively. The chemical element concentrations were measured using ICP. Table 4 gives an overview of the main sludge characteristics related to processing of textile wastewater. The ICP analysis shows the presence of the following elements: $\mathrm{Na}, \mathrm{K}, \mathrm{Ca}, \mathrm{P}, \mathrm{Mg}, \mathrm{Cu}, \mathrm{Mn}, \mathrm{Fe}, \mathrm{Zn}, \mathrm{Cd}, \mathrm{Pb}$, $\mathrm{Ni}, \mathrm{Cr}, \mathrm{Co}, \mathrm{As}, \mathrm{Se}, \mathrm{Al}$, and Mo. All elements are 
Table $\mathbf{3}$ The main characteristics of textile wastewater before and after treatment

\begin{tabular}{|c|c|c|c|c|c|c|}
\hline Characteristics & Unit & $\begin{array}{c}\text { Without } \\
\text { treatment }\end{array}$ & $\begin{array}{l}\text { After EC } \\
\text { treatment }\end{array}$ & $\begin{array}{c}\text { Removal } \\
\text { efficiency } \\
(\%)\end{array}$ & $\begin{array}{l}\text { After EC- } \\
\text { EF } \\
\text { treatment }\end{array}$ & $\begin{array}{c}\text { Removal } \\
\text { efficiency } \\
(\%)\end{array}$ \\
\hline Temperature & ${ }^{\circ} \mathrm{C}$ & 22 & 23 & - & 22 & - \\
\hline Color & & Blue black & $\begin{array}{l}\text { Almost } \\
\text { clear }\end{array}$ & - & $\begin{array}{l}\text { Almost } \\
\text { clear }\end{array}$ & - \\
\hline $\mathrm{pH}$ & & 8.75 & 8.5 & - & 3 & - \\
\hline Conductivity & $\mathrm{mS} \mathrm{cm}-1$ & 2.5 & 2.1 & - & 2 & - \\
\hline COD & & 325 & 126 & 61 & 15 & 95 \\
\hline TOC & & 52 & 34 & 35 & 2 & 96 \\
\hline BOD & & 35 & 18 & 49 & 12 & 66 \\
\hline TSS & & 49 & 5 & 90 & 1 & 98 \\
\hline TN & & 40 & 30 & 25 & 27 & 33 \\
\hline $\mathrm{NH}_{4}^{+}$ & & 2 & 1.6 & 20 & 1.1 & 45 \\
\hline $\mathrm{P}$ & & 0.2 & 0.2 & 0 & 0.1 & 50 \\
\hline $\mathrm{SO}_{4}{ }^{2-}$ & & 75 & 60 & 20 & 120 & - \\
\hline $\mathrm{Ca}$ & $m a I-1$ & 540 & 84 & 84 & 26 & 95 \\
\hline $\mathrm{k}$ & $m g L^{-1}$ & 35 & 13 & 63 & 10 & 71 \\
\hline $\mathrm{Mg}$ & & 254 & 102 & 60 & 54 & 79 \\
\hline $\mathrm{Na}$ & & 678 & 162 & 76 & 100 & 85 \\
\hline $\mathrm{Cu}$ & & 0.254 & 0.065 & 75 & 0.045 & 82 \\
\hline $\mathrm{Mn}$ & & 0.54 & 0.059 & 90 & 0.034 & 94. \\
\hline $\mathrm{Fe}$ & & 0.875 & 0.142 & 85 & 0.025 & 97 \\
\hline $\mathrm{Zn}$ & & 0.610 & 0.154 & 75 & 0.038 & 94 \\
\hline $\mathrm{Cd}$ & & 0.5 & 0.2 & 60 & 0.2 & 60 \\
\hline $\mathrm{Al}$ & & 0.657 & 0.300 & 54 & 0.152 & 77 \\
\hline $\mathrm{Pb}$ & & 15 & 5 & 67 & 5 & 67 \\
\hline $\mathrm{Ni}$ & & 14 & 4 & 71 & 4 & 71 \\
\hline $\mathrm{Cr}$ & & 27 & 7 & 74 & 5 & 81 \\
\hline $\mathrm{Ba}$ & -1 & 204 & 91 & 55 & 49 & 76 \\
\hline $\mathrm{Co}$ & $\mu \mathrm{g} \mathrm{L}^{-1}$ & 6 & $<1$ & $>85$ & $<1$ & $>85$ \\
\hline As & & 15 & 4 & 73 & 4 & 73 \\
\hline $\mathrm{Se}$ & & 24 & 11 & 54 & 4 & 83 \\
\hline $\mathrm{Hg}$ & & 0.7 & $<0.1$ & $>87$ & $<0.1$ & $>87$ \\
\hline
\end{tabular}

generally more concentrated in the decanted sludge than in the floated sludge, except for $\mathrm{Fe}$, and $\mathrm{Ni}$ ions which reached the concentrations of 24 , and $179 \mathrm{mg} / 100 \mathrm{~g}$ respectively. The electrocoagulation process has been reported to be effective in removing metals, heavy metals, non metal, anions, and organic compounds from industrial effluents [34]. The sludge contains high amounts of $\mathrm{Na}, \mathrm{Fe}, \mathrm{Cd}, \mathrm{Mo}, \mathrm{N}, \mathrm{C}, \mathrm{S}, \mathrm{P}$, and trace elements. Therefore, the generated sludge could be used in soil amendment as fertilizer to increase agricultural production [35]. Likewise, in the light of its metallic composition, the sludge could be used in cement manufactory as raw material [36].

\section{SEM and EDS analysis}

The SEM analysis is a tool for showing the morphology and shape of the sample [37]. Figure 5a and b present the micrograph obtained by SEM of floated sludge after drying at $105^{\circ} \mathrm{C}$ and after calcination at $300^{\circ} \mathrm{C}$. As the decanted and floated sludge showed the similar morphology, only the SEM micrograph of the later was presented. The micrograph revels that sludge presents aggregate shapes with non-uniform distribution of particle sizes varying from 4 to $120 \mu \mathrm{m}$. The EDS analysis show that the sludge contains various metallic element with the abundance of $\mathrm{O}>\mathrm{Fe}>\mathrm{Cr}>\mathrm{Cl}>\mathrm{Na}>\mathrm{Ni}>\mathrm{Mn}>$ $\mathrm{S}$ (Fig. 6). It is obvious that part of metallic elements is 
Table 4 Sludge characteristics for textile wastewater during treatment by EC

\begin{tabular}{lll}
\hline Elements & Sludge $(\mathrm{mg} / 100 \mathrm{~g})$ & \\
\cline { 2 - 3 } & Floated & Decanted \\
\hline $\mathrm{Na}$ & 4.6 & 18.4 \\
$\mathrm{~K}$ & 0 & 0.5 \\
$\mathrm{Ca}$ & 0.8 & 0.9 \\
$\mathrm{P}$ & 0.3 & 0.1 \\
$\mathrm{Mg}$ & 0.8 & 0.5 \\
$\mathrm{Cu}$ & 0.1 & 0.1 \\
$\mathrm{Mn}$ & 0.8 & 0.3 \\
$\mathrm{Fe}$ & 24.0 & 16.2 \\
$\mathrm{Zn}$ & 2.0 & 0.1 \\
$\mathrm{Cd}$ & 5.9 & 0 \\
$\mathrm{~Pb}$ & 1.1 & 0.3 \\
$\mathrm{Ni}$ & 179.0 & 55.7 \\
$\mathrm{Cr}$ & 95.9 & 115.0 \\
$\mathrm{Ba}$ & 0 & 0 \\
$\mathrm{Co}$ & 0.5 & 0.1 \\
$\mathrm{As}$ & 0.47 & 0 \\
$\mathrm{Se}$ & 0 & 0 \\
$\mathrm{Al}$ & 23.2 & 9.6 \\
$\mathrm{Mo}$ & 10.0 & 4.7 \\
$\mathrm{Hg}$ & 0 & 0 \\
\hline
\end{tabular}

transferred from wastewater to the sludge which requires taking into account this drawback in its subsequent treatment.

\section{$X R D$ analysis}

Figure 7a shows the XRD diffractogram of dried sludge which exhibits a pure $\mathrm{NaCl}$ structure in accordance with JCPDS 05-0628 card. The two intense peaks located at $2 \theta=31.7^{\circ}$ and $2 \theta=45.5^{\circ}$ correspond respectively to the

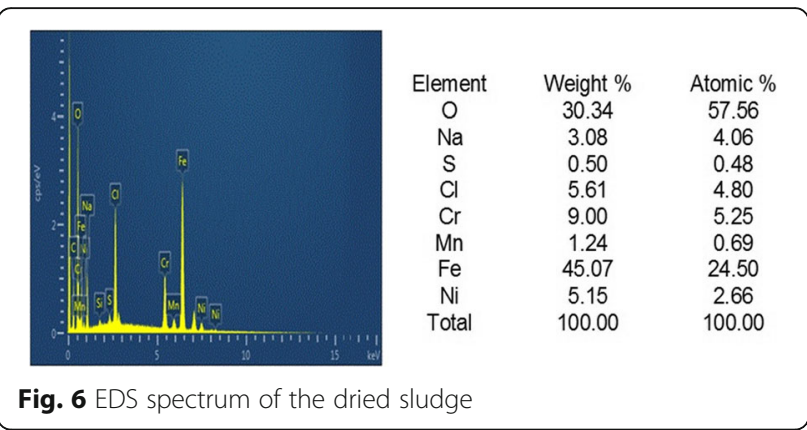

(200) and (220) planes. No evidence was found to support the presence of metallic oxides in crystalline form. Furthermore, the sludge was sonically washed in distilled water for $30 \mathrm{~min}$ to get rid of $\mathrm{NaCl}$ salt. The obtained XRD spectrum is displayed in Fig. 7b and no crystalline phase (amorphous compounds) could be identified. In addition, the background signal increased with the diffraction angle. $\mathrm{NaCl}$ was totally eliminated by washing and the background of the diffractogram is quite high characteristic of the presence of an element that gives fluorescence with the copper radiation or characteristic of materials in nanostructured form. In order to obtain information of these assumptions, high resolution TEM analysis was undertaken to control the shape of the studied compound. Figure 8 shows the TEM micrographs of the free $\mathrm{NaCl}$ sludge. According to these micrographs, the size of the sludge-derived particles is less than $1 \mathrm{~nm}$. The sludge obtained after EC treatment contains mainly organic matter and metallic oxy/hydroxides. Heat treatment at $300{ }^{\circ} \mathrm{C}$ removes the organic matter and forms amorphous oxide containing $\mathrm{NaCl}$ crystals. After washing, magnetic nanomaterial oxides are obtained and they can be attracted by a magnet. Recently, Waller et al. [38] have synthesized magnetic FeOx nanoparticles during the treatment of oil/salt water emulsions (bilge water), by EC process using iron
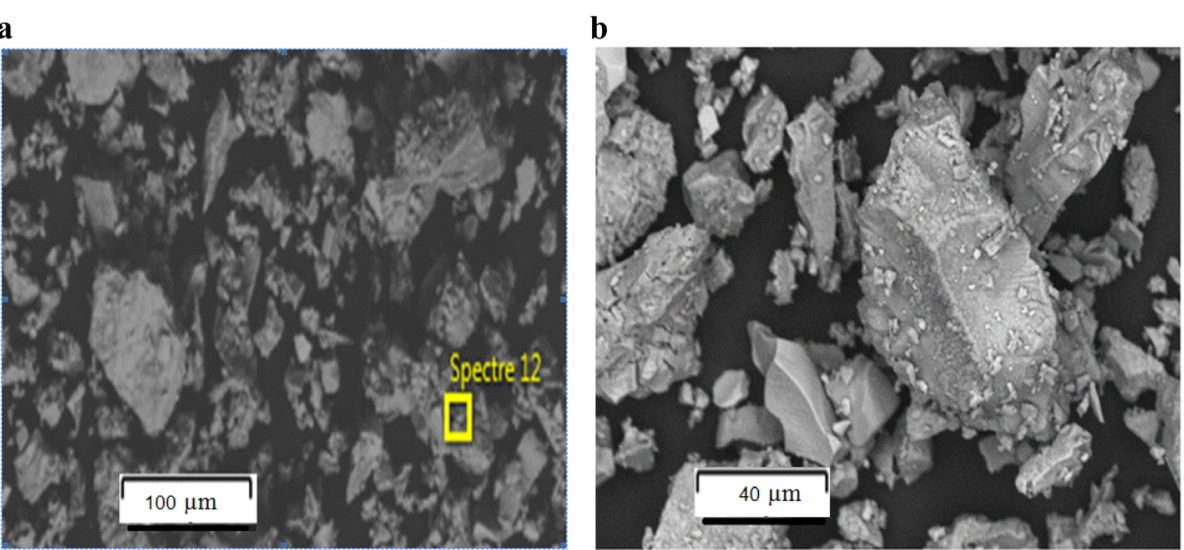

Fig. 5 Floated sludge SEM Micrographs, (a) dehydrated and (b) calcined sludge 

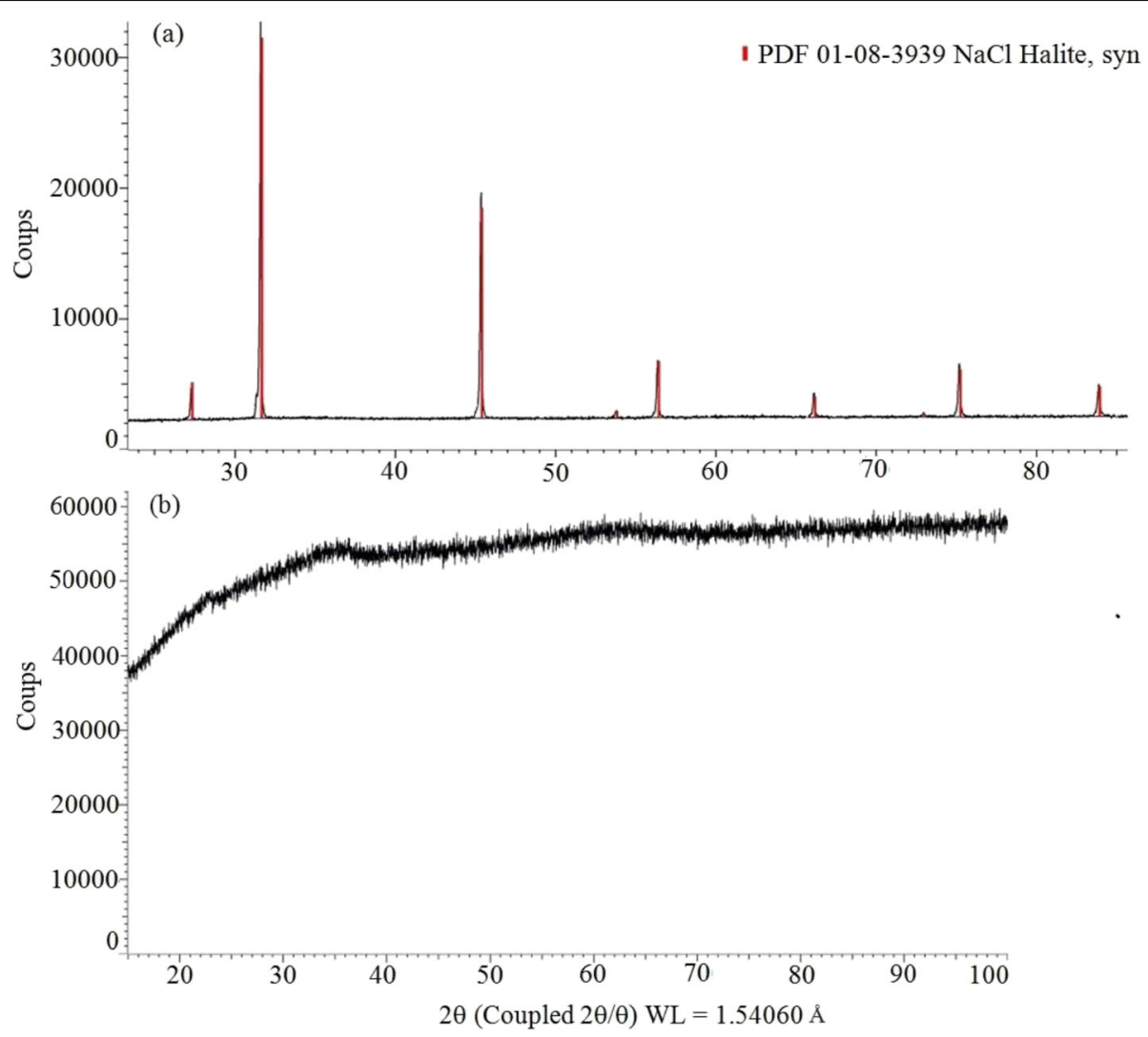

Fig. 7 XRD diffractograms of (a) dried sludge; (b) the salt free sludge

anode. The EC precipitates were highly sensitive to a permanent magnet. Complete settling of the suspended particles required only $5 \mathrm{~min}$ under the influence of a permanent magnet while a large amount of precipitate remained suspension in solution after $1 \mathrm{~h}$ of natural settling. In addition, the iron oxide nanoparticles have been described in the literature for having potential applications in wastewater treatments [39]. The use of magnetic oxides as adsorbents of pollutants in aqueous solution is becoming a potential method in textile wastewater treatment and found to be more effective compared to conventional method of treatments [40]. Magnetic separation of adsorbents has been one of the promising techniques for wastewater treatment. The pollutant covered sorbent is magnetically extracted from the solution which avoids filtration. The study of adsorption of dyes on these nanomaterials is an ongoing study in our lab.

For further characterization of the free salt sludge, EDS measurements were performed for elemental analysis. Figure 9 shows the EDS spectra with oxygen, iron,

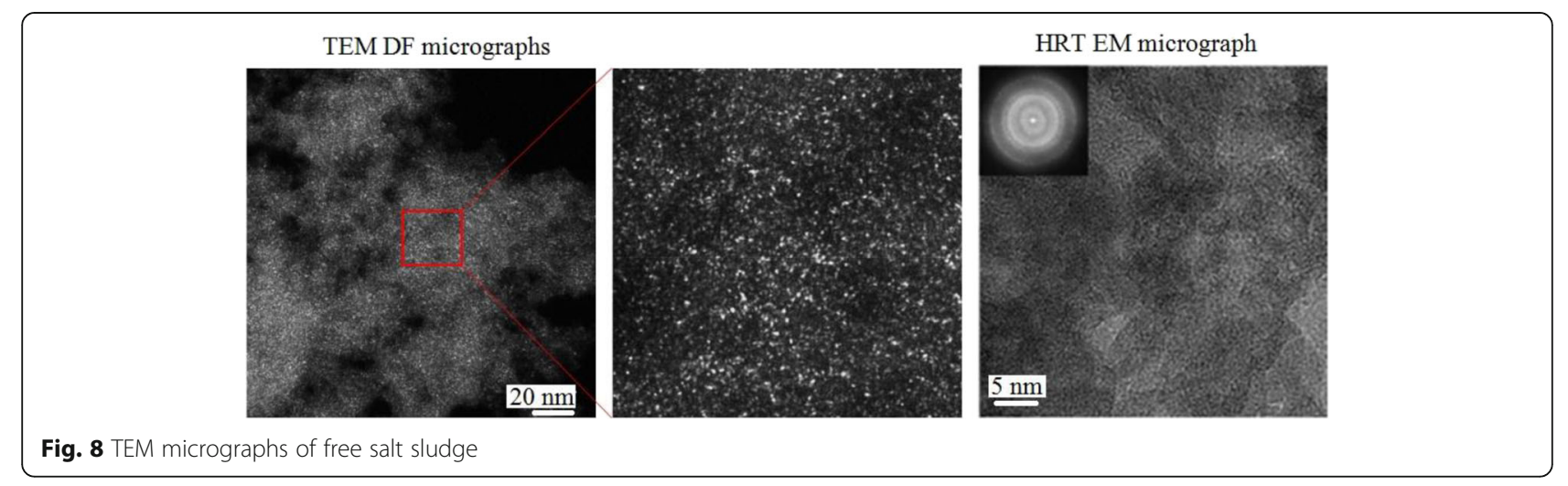




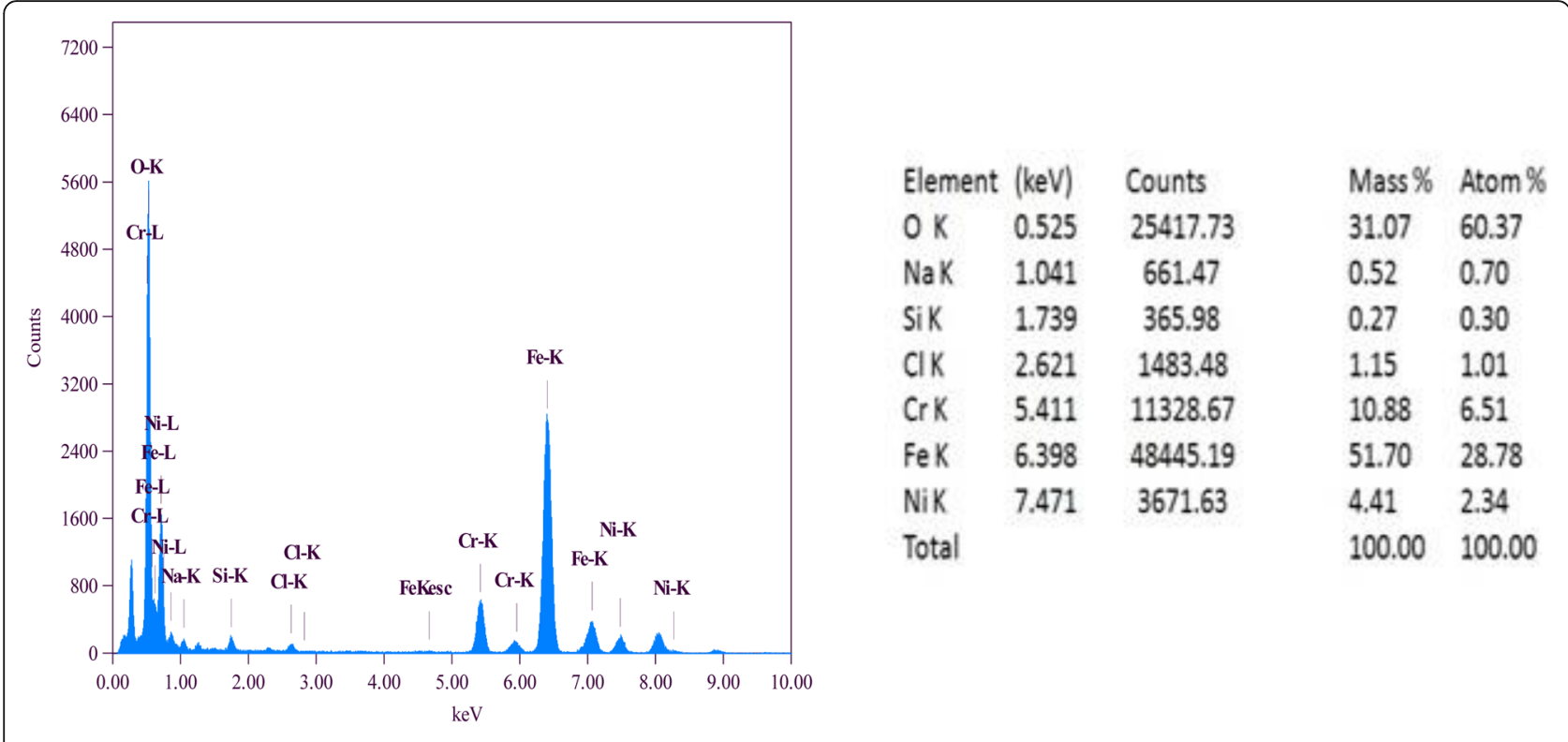

Fig. 9 Energy-dispersive X-ray spectroscopy spectra of the free salt sludge

chromium, and nickel as major elements. The ratio $\mathrm{O} /$ $(\mathrm{Fe}+\mathrm{Cr}+\mathrm{Ni})=1.6$ which is almost equal to that of $\mathrm{Fe}_{2} \mathrm{O}_{3}$ oxide, i.e., 1.5. Moreover, these nanostructured particles are attracted by a magnet which reinforces this assumption. An important advantage for using iron electrodes in EC stems from the fact that Fe is non-toxic for biota and the iron sludge is significantly denser than $\mathrm{Al}$ sludge, therefore it occupies less space and needs less energy for dehydration [41].

Furthermore, treatment of textile effluents can lead to the formation of other complexes like jarosite [42]. It is a family of iron-hydroxysulphate minerals which are formed along with other compounds during wastewater treatment and acted as scavenger of iron ions and other toxic elements. These compounds are formed in acidic media, iron sulfate-rich environment, high temperature and pressure, and long reaction time [43]. Thus, $\mathrm{X}$ ray diffractogram does not show specific peaks of the jarosite, our operating conditions are far from those allowing its formation.

\section{Conclusions}

Hybrid electrochemical processes EC, EC-EF, EC-AO and $\mathrm{EC}-\mathrm{PC}$ were investigated to treat real textile wastewater. The findings indicated that the effectiveness of the treatment decreases in the sequence $\mathrm{EC}-\mathrm{EF}>\mathrm{EC}$ $\mathrm{AO}>\mathrm{EC}-\mathrm{PC}>\mathrm{EC}$. The combination EC-EF treatment leads to high color and TOC removal of real textile wastewater containing mainly methylene blue (up to over 97\%). EC treatment as a single process is not efficient for the elimination of dye organic stuff. The energy consumption using the integrated process was less than that of EC alone. In accordance with this approach, the energy consumption is reduced from $3 \mathrm{kWh} \mathrm{kg}^{-1}$ of removed TOC in the case of EC to $0.45 \mathrm{kWh} \mathrm{kg}^{-1}$ of removed TOC when EC is coupled with EF. EC-EF process can reduce the $\mathrm{COD}$ and increase the $\mathrm{BOD} /$ COD ratio after $60 \mathrm{~min}$ of electrolysis, which leads to increasing the biodegradability of the effluent by $75 \%$. Efficient removal for metal ions is obtained by enhanced precipitation and flotation of the sludge during EC treatment for reuse purpose. The floated and decanted sludge are analyzed in terms of metallic element and their morphology characterized. These materials contained heavy metals which initially exist in the wastewater and are mainly composed by $\mathrm{NaCl}$ salt. Free salt sludge shows nanostructured shapes with size of less than 1 $\mathrm{nm}$. Thus, sludge issued of wastewater treatment can be a precursor of nanostructure materials. More, the ratio oxygen/metallic elements is in favor of a form of oxide that approaching $\mathrm{Fe}_{2} \mathrm{O}_{3}$. Further work is ongoing in our laboratory to better characterize the obtained sludge in terms of composition, specific surface, catalytic and magnetic properties.

\section{Acknowledgements}

The authors would like to thank the University of Ibn Zohr, Agadir, for making all the necessary resources available for this work.

\section{Authors' contributions}

All authors proposed the study and participated in writing the manuscript. $\mathrm{HA}$ carried out the lab experimental studies and edit the manuscript, $\mathrm{HZ}$ carried out the physicochemical parameters. FET participated in experimental studies. RAA participated in the characterization of materials and drafted the manuscript. YR carried out the wastewater analysis (ICP). AE participated in the design of the study and performed the sludge characterization and participated in its coordination. JG carried out SEM, EDS TEM, XRD. MH 
conceived of the study and participated in its coordination. All authors read and approved the final manuscript.

\section{Funding}

This work is done in the framework of the European ERANET MED Water13_043 project SETPROpER: (Sustainable treatment processes of effluents for reuse of water in agriculture) with the financial support of MOROCCAN MESRSFC.

\section{Availability of data and materials}

All data generated or analyzed during this study are recorded from experimentation.

\section{Competing interests}

The authors declare that they have no competing interests.

\section{Author details}

'Chemical Department, Ibn Zohr University, 80060 Agadir, Morocco.

${ }^{2}$ Chemical Department, Hassan II University, 28806 Mohammedia, Morocco.

${ }^{3}$ Jean Lamour Institute, Lorraine University, 54011 Nancy, France.

\section{Received: 9 September 2019 Accepted: 23 December 2019}

Published online: 09 January 2020

\section{References}

1. Samanta KK, Pandit P, Samanta P, Basak S. Water consumption in textile processing and sustainable approaches for its conservation. In: Muthu SS, editor. Water in textiles and fashion. Duxford: Woodhead Publishing; 2019. p. 41-59.

2. Gong RM, Zhu SX, Zhang DM, Chen J, Ni SJ, Guan R. Adsorption behavior of cationic dyes on citric acid esterifying wheat straw: kinetic and thermodynamic profile. Desalination. 2008;230:220-8

3. Guadie A, Tizazu S, Melese M, Guo W, Ngo HH, Xia S. Biodecolorization of textile azo dye using Bacillus sp. strain $\mathrm{CH} 12$ isolated from alkaline lake. Biotechnol Rep (Amst). 2017;15:92-100.

4. Koroglu EO, Yoruklu HC, Demir A, Ozkaya B. Scale-up and commercialization issues of the MFCs: challenges and implications. In: Mohan SV, Varjani S, Pandey A, editors. Microbial electrochemical technology. Amsterdam: Elsevier; 2019. p. 565-83.

5. Kumar PS, Saravanan A. Sustainable wastewater treatments in textile sector. In: Muthu SS, editor. Sustainable fibres and textiles. Duxford: Woodhead Publishing; 2017. p. 323-46.

6. Rovina K, Prabakaran PP, Siddiquee S, Shaarani SM. Methods for the analysis of sunset yellow FCF (E110) in food and beverage products- a review. TrAC Trend Anal Chem. 2016:85:47-56.

7. Pan HM, Feng JH, Cerniglia CE, Chen HZ. Effects of Orange II and Sudan III azo dyes and their metabolites on Staphylococcus aureus. J Ind Microbio Biot. 2011;38:1729-38.

8. Brahmi K, Bouguerra W, Hamrouni B, Elaloui E, Loungou M, Tlili Z. Investigation of electrocoagulation reactor design parameters effect on the removal of cadmium from synthetic and phosphate industrial wastewater. Arab J Chem. In press.

9. Linares-Hernandez I, Barrera-Diaz C, Bilyeu B, Juarez-GarciaRojas P, Campos Medina E. A combined electrocoagulation-electrooxidation treatment for industrial wastewater. J Hazard Mater. 2010;175:688-94.

10. Bazrafshan E, Mohammadi L, Ansari-Moghaddam A, Mahvi AH. Heavy metals removal from aqueous environments by electrocoagulation processa systematic review. J Environ Health Sci. 2015;13:74.

11. Dominguez CM, Oturan N, Romero A, Santos A, Oturan MA. Optimization of electro-Fenton process for effective degradation of organochlorine pesticide lindane. Catal Today. 2018;313:196-202.

12. Oturan MA, Aaron JJ. Advanced oxidation processes in water/wastewater treatment: principles and applications. A review. Crit Rev Env Sci Tec. 2014 44:2577-641.

13. Zazou H, Oturan N, Zhang H, Hamdani M, Oturan MA. Comparative study of electrochemical oxidation of herbicide 2,4,5-T: kinetics, parametric optimization and mineralization pathway. Sustain Environ Res. 2017;27:15-23.

14. Daghrir R, Drogui P. Coupled electrocoagulation-electro-Fenton for efficient domestic wastewater treatment. Environ Chem Lett. 2013;11:151-6.
15. Garcia-Garcia A, Martinez-Miranda V, Martinez-Cienfuegos IG, AlmazanSanchez PT, Castaneda-Juarez M, Linares-Hernandez I. Industrial wastewater treatment by electrocoagulation-electrooxidation processes powered by solar cells. Fuel. 2015;149:46-54.

16. Akyol A. Treatment of paint manufacturing wastewater by electrocoagulation. Desalination. 2012;285:91-9.

17. Bayramoglu M, Kobya M, Can OT, Sozbir M. Operating cost analysis of electrocoagulation of textile dye wastewater. Sep Purif Technol. 2004:37:117-25

18. Kumar A, Nidheesh PV, Kumar MS. Composite wastewater treatment by aerated electrocoagulation and modified peroxi-coagulation processes. Chemosphere. 2018;205:587-93.

19. Hernandez-Ortega M, Ponziak T, Barrera-Diaz C, Rodrigo MA, Roa-Morales G, Bilyeu B. Use of a combined electrocoagulation-ozone process as a pretreatment for industrial wastewater. Desalination. 2010;250:144-9.

20. Roa-Morales G, Campos-Medina E, Campos-Medina E, Bilyeu B, Barrera-Diaz C. Aluminum electrocoagulation with peroxide applied to wastewater from pasta and cookie processing. Sep Purif Technol. 2007;54:124-9.

21. Zazou $\mathrm{H}$, Afanga $\mathrm{H}$, Akhouairi $\mathrm{S}$, Ouchtak $\mathrm{H}$, Addi AA, Akbour RA, et al. Treatment of textile industry wastewater by electrocoagulation coupled with electrochemical advanced oxidation process. J Water Process Eng. 2019;28:214-21.

22. Jouanneau S, Recoules L, Durand MJ, Boukabache A, Picot V, Primault $Y$, et al. Methods for assessing biochemical oxygen demand (BOD): a review. Water Res. 2014:49:62-82.

23. Thompson M, Owen L, Wilkinson K, Wood R, Damant A. A comparison of the Kjeldahl and dumas methods for the determination of protein in foods, using data from a proficiency testing scheme. Analyst. 2002;127:1666-8.

24. Harwood JE, Kuhn AL. A colorimetric method for ammonia in natural waters. Water Res. 1970:4:805-11.

25. Ismail AF, Khulbe KC, Matsuura T. RO membrane fouling. In: Ismail AF, Khulbe KC, Matsuura T, editors. Reverse osmosis. Amsterdam: Elsevier; 2019. p. 189-220.

26. Ghanbari F, Moradi M. A comparative study of electrocoagulation, electrochemical Fenton, electro-Fenton and peroxi-coagulation for decolorization of real textile wastewater: electrical energy consumption and biodegradability improvement. J Environ Chem Eng. 2015;3:499-506.

27. Al-Shannag M, Lafi W, Bani-Melhem K, Gharagheer F, Dhaimat O. Reduction of COD and TSS from paper industries wastewater using electro-coagulation and chemical coagulation. Sep Sci Technol. 2012;47:700-8.

28. Bener S, Bulca O, Palas B, Tekin G, Atalay S, Ersoz G. Electrocoagulation process for the treatment of real textile wastewater: effect of operative conditions on the organic carbon removal and kinetic study. Process Saf Environ. 2019;129:47-54

29. Nippatla N, Philip L. Electrocoagulation-floatation assisted pulsed power plasma technology for the complete mineralization of potentially toxic dyes and real textile wastewater. Process Saf Environ. 2019:125:143-56.

30. Celebi MS, Oturan N, Zazou H, Hamdani M, Oturan MA. Electrochemical oxidation of carbaryl on platinum and boron-doped diamond anodes using electro-Fenton technology. Sep Purif Technol. 2015;156:996-1002.

31. Guvenc SY, Dincer K, Varank G. Performance of electrocoagulation and electro-Fenton processes for treatment of nanofiltration concentrate of biologically stabilized landfill leachate. J Water Process Eng. 2019;31:100863.

32. Ozcan A, Gencten M. Investigation of acid red 88 oxidation in water by means of electro-Fenton method for water purification. Chemosphere. 2016; 146:245-52.

33. Ahmad T, Ahmad K, Alam M. Characterization of water treatment plant's sludge and its safe disposal options. Procedia Environ Sci. 2016;35:950-5.

34. Moreno-Casillas HA, Cocke DL, Gomes JAG, Morkovsky P, Parga JR, Peterson $E$, et al. Electrochemical reactions for electrocoagulation using iron electrodes. Ind Eng Chem Res. 2009;48:2275-82.

35. Rosa EVC, Mater L, Souza-Sierra MM, Rorig LR, Vieira LM, Radetski CM. Textile sludge application to non-productive soil: physico-chemical and phytotoxicity aspects. Ecotox Environ Safe. 2007;68:91-7.

36. Arfala Y, Douch J, Assabbane A, Kaaouachi K, Tian HZ, Hamdani M. Assessment of heavy metals released into the air from the cement kilns coburning waste: case of Oujda cement manufacturing (Northeast Morocco). Sustain Environ Res. 2018;28:363-73.

37. Li YF, Yuan XZ, Wu ZB, Wang H, Xiao ZH, Wu Y, et al. Enhancing the sludge dewaterability by electrolysis/electrocoagulation combined with zero-valent iron activated persulfate process. Chem Eng J. 2016;303:636-45. 
38. Waller GH, Martin CA, Jones NJ, Paynter DM. Treatment of oil-in-saltwater emulsions by in-situ production of magnetic $\mathrm{FeO}_{x}$ nanoparticles. J Water Process Eng. 2019;31:100851.

39. Ramimoghadam D, Bagheri S, Hamid SBA. Progress in electrochemical synthesis of magnetic iron oxide nanoparticles. J Magn Magn Mater. 2014; 368:207-29.

40. Sivashankar R, Sathya AB, Vasantharaj K, Sivasubramanian V. Magnetic composite an environmental super adsorbent for dye sequestration - a review. Environ Nanotechno Monit Manage. 2014;1-2:36-49.

41. Staicu LC, van Hullebusch ED, Lens PNL, Pilon-Smits EAH, Oturan MA. Electrocoagulation of colloidal biogenic selenium. Environ Sci Pollut R. 2015; 22:3127-37.

42. Xu ZH, Liang JR, Zhou LX. Photo-Fenton-like degradation of azo dye methyl orange using synthetic ammonium and hydronium jarosite. J Alloy Compd. 2013:546:112-8.

43. Islas H, Flores MU, Reyes IA, Juarez JC, Reyes M, Teja AM, et al. Determination of the dissolution rate of hazardous jarosites in different conditions using the shrinking core kinetic model. J Hazard Mater. In press.

\section{Publisher's Note}

Springer Nature remains neutral with regard to jurisdictional claims in published maps and institutional affiliations.

Ready to submit your research? Choose BMC and benefit from:

- fast, convenient online submission

- thorough peer review by experienced researchers in your field

- rapid publication on acceptance

- support for research data, including large and complex data types

- gold Open Access which fosters wider collaboration and increased citations

- maximum visibility for your research: over $100 \mathrm{M}$ website views per year

At BMC, research is always in progress.

Learn more biomedcentral.com/submissions 